\title{
Respon Siswa MTs Swasta Al-UMM terhadap Pembelajaran Daring Selama Pandemi Corona
}

\author{
Risna Mira Bella Saragih ${ }^{1}$, Khoiruddin Matondang ${ }^{2}$, Nila Wati ${ }^{3}$ \\ 1, 2, 3 Prodi Pendidikan Matematika FKIP Univa Medan, Jl. Sisingamangaraja No. 10 Sumut \\ risnamirabellasaragih@gmail.com
}

\begin{abstract}
The emergence of the Covid-19 pandemic has an impact on learning activities in schools. Learning activities continue even in a pandemic situation which is carried out online. This online learning is carried out by teachers and students in separate places. Through several applications that are already available such as whattsAps group, google form, google classroom, google meet, zoom meeting and others. This study aims to: Determine the response of Al-UMM Medan Marelan students to online learning during the 2020/2021 T.P pandemic. This research is a qualitative research. The data collection tool in this study was a questionnaire. The questionnaire used is a questionnaire in the form of 20 questions. Questionnaires are used to find out students' responses to online learning during the pandemic. From the results of the 45 students' questionnaire, it was found that from the indicators showing an interest in online learning in terms of the teacher there were $(57.53 \%)$ with less positive criteria, indicators showing an interest in online learning in terms of learning media there were $(47.77 \%)$ with less positive criteria and indicators show interest in online learning in terms of supporting facilities / supporting facilities (51.66\%) with less positive criteria. The conclusion of this study is that the response of AL-UMM Private MTS students is less positive about online learning during the Corona pandemic.
\end{abstract}

Keywords: Student response, online learning.

\begin{abstract}
Abstrak
Munculnya pandemi Covid-19 memberikan dampak bagi kegiatan pembelajaran di Sekolah. Kegiatan pembelajaran tetap berjalan meskipun dalam situasi pandemi yang dilakukan secara daring (online). Pembelajaran online ini dilakukan guru dan siswa di tempat yang terpisah. melalui beberapa aplikasi yang sudah tersedia seperti whattsAps group, google form, google classroom, google meet, zoom meeting dan lain-lain. Penelitian ini bertujuan untuk: Mengetahui respon siswa MTs Swasta Al-UMM Medan Marelan terhadap pembelajaran daring selama pandemi T.P 2020/2021. Penelitian ini merupakan penelitian Kualitatif. Alat pengumpul data dalam penelitian ini adalah berupa angket. Angket yang digunakan adalah angket yang berupa 20 butir pertanyaan. Angket digunakan untuk dapat mengetahui respon siswa pada saat belajar daring selama pandemi. Respon siswa yang dimaksud dalam penelitian ini adalah respon terhadap pembelajaran yang dilakukan oleh guru selama daring. Dari hasil angket 45 siswa diperoleh bahwa dari indikator menunjukan minat terhadap pembelajaran daring ditinjau dari pembelajaran yang dilaksanakan guru terdapat $(57,53 \%)$ dengan kriteria kurang positif, indikator menunjukan minat terhadap pembelajaran daring ditinjau dari media pembelajaran terdapat $(47,77 \%)$ dengan kriteria kurang positif dan indikator menunjukan minat terhadap pembelajaran daring ditinjau dari sarana pendukung/fasilitas pendukung juga terdapat $(51,66 \%)$ dengan kriteria kurang positif. Kesimpulan dari penelitian ini adalah respon siswa MTS Swasta AL-UMM kurang positif terhadap pembelajaran daring selama pandemi Corona.
\end{abstract}

Kata kunci: Respon siswa, pembelajaran daring

Copyright (c) 2021 Risna Mira Bella Saragih, Khoiruddin Matondang, Nila Wati

$\bowtie$ Corresponding author: Risna Mira Bella Saragih

Email Address: risnamirabellasaragih@gmail.com (Jl. Sisingamangaraja No. 10 Sumut)

Received 10 November 2020, Accepted 12 Maret 2021, Published 27 Juni 2021

\section{PENDAHULUAN}

Adanya wabah Covid-19 membawa perubahan besar dalam tatanan pendidikan di Indonesia. Sejak maret 2020 hingga saat ini pembelajaran di sekolah dilaksanakan secara jarak jauh. Hal tersebut sesuai dengan Surat Edaran Kementerian Pendidikan dan Kebudayaan No. 1 tahun 2020. Pendidikan dituntun 
untuk dapat menyelenggarakan pembelajaran secara daring. Menurut (Padli \& Rusdi, 2020) pada saat pandemi mengubah sistem pembelajaran yang mengharuskan guru beradaptasi menggunakan pembelajaran online seperti Google Classroom, WhatsApp Group, Google meet, Zoom. (Handarini \& Wulandari, 2020) menyatakan dampak covid 19 pada kegiatan belajar mengajar cukup terasa, terlihat dari pembelajaran yang semestinya dilakukan secara langsung sekarang dilakukan secara mandiri di rumah. Yayasan Perguruan Mandiri MTs Swasta Al-UMM yang beralamat JL. Danau Siombak LK. I Kel. Labuhan Deli Kec. Medan Marelan telah mengambil kebijakan langkah belajar dari rumah melalui pembelajaran daring selama pandemi berlangsung. Kegiatan pembelajaran yang dilaksanakan dari rumah dengan cara penugasan dan koordinasi terkait penugasan yang diberikan melalui aplikasi whatsapp antara siswa dan pendidik.

Selayaknya proses PJJ tidak banyak mengurangi esensi dari tujuan pembelajaran matematika. Akan tetapi belajar matematika dengan konsep PJJ merupakan hal yang asing dan menimbulkan masalah tersendiri bagi siswa. Kenyataan di lapangan masih banyak siswa yang menganggap matematika pelajaran yang sulit. Terlebih saat PJJ siswa tidak berjumpa dengan guru, siswa tidak bisa bertanya secara langsung menanyakan kendala saat belajar. Belajar matematika selama PJJ menimbulkan problem tersendiri bagi siswa. Siswa kurang memahami pelajaran secara mandiri, siswa tidak bisa memahami materi dari modul dan buku. Sebagaimana pernyataan (Utami et al., 2020) masalah yang sering dialami siswa selama belajar online siswa kurang memiliki inisiatif belajar mandiri, siswa hanya menunggu instruksi dari guru, tujuan siswa dalam belajar online matematika berfokus pada perolehan nilai saja, bukan kemampuan yang seharusnya mereka tingkatkan, siswa menyerah ketika mendapat kesulitan dan kesalahan ketika mengerjakan tugas online matematika.

Problematika saat ini adalah masih banyak peserta didik yang menganggap matematika pelajaran yang sulit. Sebagaimana pendapat (Auliya, 2016) yang menyatakan bahwa matematika dianggap sebagai pelajaran yang sulit karena karakteristik matematika yang bersifat abstrak, logis, sistematis, dan penuh dengan lambang serta rumus yang membingungkan. Persepsi siswa tersebut harus diimbangi dengan kemampuan guru dalam merancang pembelajaran yang menarik dan mudah dipahami, terlebih saat daring. Menggunakan media pembelajaran daring yang tepat, sehingga siswa bisa memahami materi dengan baik dan senang belajar matematika. (Utami et al., 2020) mengungkapkan masalah kesulitan siswa yang sering terjadi selama daring, siswa belum terbiasa dalam melaksanakan kebutuhan belajar online dirumah, masih ada siswa yang menyerah mengerjakan tugas e-learning matematika ketika terdapat kesulitan. (Utami et al., 2020) menyatakan pembelajaran daring tidaklah mudah jika dibanding dengan sistem pembelajaran face-to face. Ada kemungkinan hal tersebut terjadi karena guru tidak mampu menerapkan inovasi pembelajaran daring.

Masa pandemi ini pembelajaran jarak jauh dapat terlaksana dengan menggunakan berbagai platform, baik berupa learning management system maupun bentuk video conference. Learning management system yang banyak digunakan diantaranya, google classroom dan porta-portal e-learning. Aplikasi video conference yang banyak digunakan selama pembelajaran jarak jauh diantaranya, aplikasi google meet, zoom 
Respon Siswa MTs Swasta Al-UMM terhadap Pembelajaran Daring Selama Pandemi Corona, Risna Mira Bella Saragih

dan visco webex. Selain aplikasi-aplikasi tersebut, Whatsapp Group pun menjadi alternatif dalam pelaksanaan pembelajaran jarak jauh (Abdul Latip, 2020).

Keberhasilan pembelajaran jarak jauh sangat tergantung pada guru, kesiapan guru dalam mempersiapkan PJJ, tanggung jawab untuk mengayomi siswa, penggunaan aplikasi IT dalam pembelajaran, pemilihan media pembelajaran yang sesuai dengan PJJ. Guru harus mampu mendesain pembelajaran yang menarik dan tidak menimbulkan rasa bosan bagi siswa. Sebagaimana pendapat Abdullah (Wahyono et al., 2020) guru harus siap dengan berbagai kondisi pembelajaran dan kondisi siswa, termasuk perkembangan kehidupan di masyarakat saat pembelajaran daring. Peran guru dalam pembelajaran jarak jauh membuat pembelajaran yang menyenangkan dan menyampingkan ancaman, salah satu caranya adalah mendesain pembelajaran yang membuat siswa tertarik dan senang belajar matematika (Suhery et al., 2020)

Hasil penelitian (Yustika et al., 2019) menyatakan siswa merasaa cemas karena kurangnya interaksi dan komunikasi dengan teman-temannya saat pembelajaran daring. Kurangnya kegiatan belajar berkelompok menjadi faktor kurangnya motivasi siswa dalam belajar. Berbeda dengan hasil penelitian (Padli \& Rusdi, 2020) yang menyatakan siswa senang belajar dengan sistem online walaupun terdapat beberapa kendala pada fasilitas internet dan biaya yang perlu dikeluarkan. Efektifitas dari pembelajaran daring dipengaruhi oleh faktor ekonomi, faktor sosial, faktor Kesehatan dan faktor kepribadian (Baety, D \& Munandar, D, 2021). Hasil penelitian (Fauzy \& Nurfauziah, 2021) menyatakan belajar daring matematika sulit karena terbatasnya ruang interaksi guru dan siswa, banyaknya rumus yang digunakan dalam matematika, objek yang dipelajari dalam matematika memiliki pola abstrak.

Sesuai kebijakan pemerintah siswa MTs Swasta AL-UMM mengadakan pembelajaran daring dari rumah. Pembelajaran tidak dapat dilakukan dengan tatap muka (luring) untuk menghindari terjadinya penyebaran Corona Virus Diseases 2019 (COVID-19). Dari hasil penelitian yang telah dijelaskan di atas menunjukkan penilaian positif dan negatif terhadap pembelajaran daring. Berdasarkan penjelasan diatas maka peneliti ingin mengetahui lebih lanjut tentang "Respon Siswa MTs Swasta Al-UMM Terhadap Pembelajaran Daring Selama Pandemi Corona".

\section{METODE}

Metode penelitian yang digunakan dalam penelitian ini adalah kualitatif. Penelitian kualitatif difokuskan pada satu fenomena saja yang dipilih dan ingin dipahami secara mendalam, dengan mengabaikan fenomenafenomena lainnya (Sukmadinata, 2017) . Langkah penelitian dapat dilihat pada Gambar 1.

Jenis penelitian

Penelitian yang dilakukan adalah penelitian kualitatif. Penelitian ini bersifat deskriptif karena bertujuan untuk membuat deskripsi, gambaran secara sistematis atau terperinci tentang respon siswa terhadap bagaimana respon siswa MTs Swasta Al-UMM terhadap pembelajaran daring yang dilaksanakan selama pandemi corona berdasarkan fakta-fakta yang ada. Adapun pendekatan kualitatif dalam penelitian ini menghasilkan data deskriptif berupa respon yang diisi siswa MTs Swasta Al-UMM melalui angket 
sebanyak 20 item pertanyaan dalam google form yang disebarkan peneliti melalui whatsapp grups. Road Map penelitian dapat dilihat pada Gambar 2.

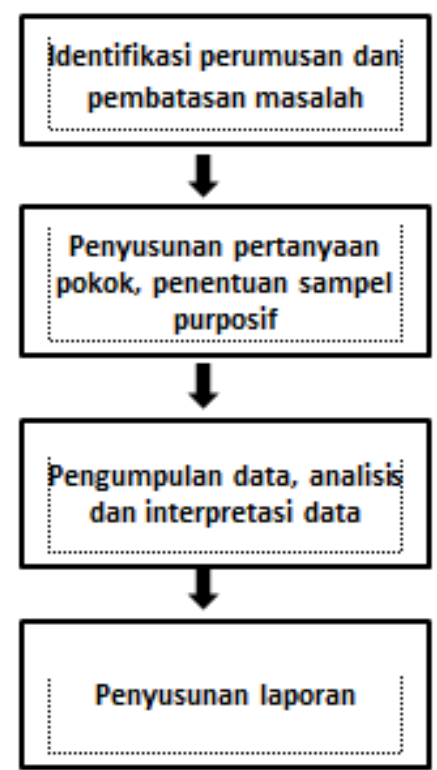

Gambar1. Langkah penelitian kualitatif (Sumber: Sukmadinata, 2017)

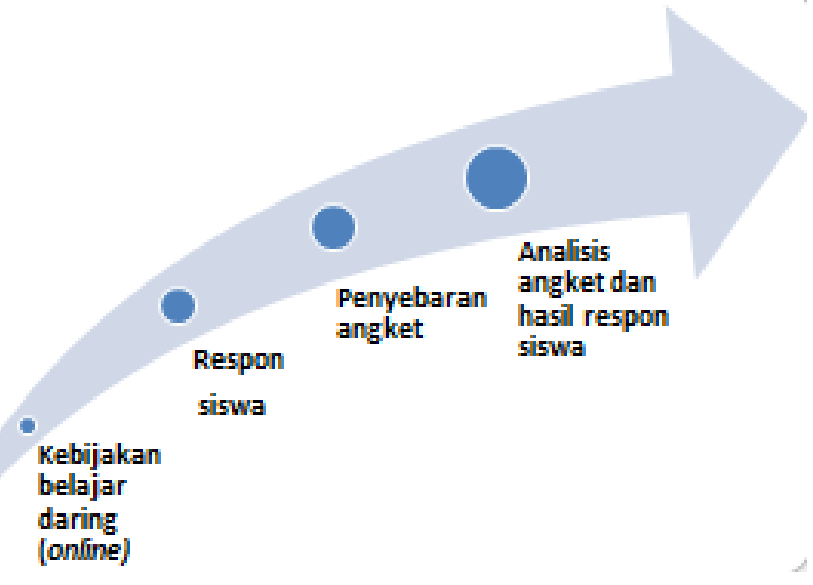

Gambar 2. Road Map Penelitian

\section{Subjek Penelitian}

Penelitian ini dilaksanakan di MTs Swasta Al-UMM yang berlokasi di Jalan Danau Siombak Lk. I Kelurahan Labuhan Deli, Kecamatan Medan Marelan, Kota Medan. Populasi dalam penelitian ini adalah seluruh siswa kelas Swasta Al-UMM tahun pembelajaran 2020/2021, berjumlah 151 siswa. Sampel penelitian terdiri dari 45 orang siswa. Teknik sampel yang digunakan dalam penelitian ini adalah purposive sampling. Menurut (Sugiono, 2017) menyatakan "purposive sampling adalah teknik pengambilan sampel sumber data dengan pertimbangan tertentu. Alasan menggunakan teknik Purposive Sampling adalah karena tidak semua sampel memiliki kriteria yang sesuai dengan fenomena yang diteliti. Oleh karena itu, penulis 
memilih teknik Purposive Sampling yang menetapkan pertimbangan-pertimbangan atau kriteria-kriteria tertentu yang harus dipenuhi oleh sampel-sampel yang digunakan dalam penelitian ini. Dalam penelitian ini yang menjadi sampel yaitu perusahaan yang memenuhi kriteria tertentu. Adapun kriteria yang dijadikan sebagai sampel penelitian yaitu: siswa yang mempunyai HP android dan mempunyai paket dan akses internet lancar.

\section{Teknik dan Instrumen Pengumpulan Data}

Teknik pengumpulan data yang digunakan dalam penelitian ini berupa angket respon siswa yang berbentuk link dari aplikasi google form, kemudian dibagikan kepada peserta didik melalui aplikasi whatsapp. Angket respon siswa menggunakan skala Likert. Sebelum digunakan angket telah divalidasi terlebih dahulu oleh 2 (dua) orang validator yaitu Bapak Siswadi, M.Pd dan Ibu Minta Ito Simamora, M.Pd hal ini berguna untuk mengetahui apakah angket yang digunakan layak disebarluaskan kepada siswa. dengan menggunakan lembar validasi angket untuk mengetahui penilaian ahli terhadap angket yang dibuat. Validasi angket yang digunakan dalam penelitian ini adalah validasi konstruksi (Construct validity). Lembar validasi angket meliputi aspek isi dan bahasa. Hasil validasi ahli menujukkan angket layak digunakan dengan perbaikan. Setelah angket di validasi oleh validator, maka dapat diketahui apa saja kelemahan yang terdapat pada angket tersebut. Setelah diketahui permasalahannya akan dijadikan bahan perbaikan dan pertimbangan agar angket layak digunakan. Sehingga angket tersebut siap digunakan untuk penelitian kualitatif yang menggunakan skala likert. Validasi yang dilakukan oleh Bapak Siswadi, M.Pd selaku validator pertama angket yang akan disebarkan kepada siswa layak digunakan tanpa adanya saran, komentar ataupun perbaikan. Sedangkan jawaban hasil validasi angket yang diberikan kepada Ibu Minta Ito Simamora, M.Pd selaku validator kedua memberikan saran atau komentar untuk penggunaan bahasa lebih sederhana dan juga lebih komunikatif.

\section{Analisis Data}

Analisa data yang digunakan adalah statistik deskriptif. Melihat respon siswa terhadap PJJ yang dilakukan. Adapun langkah-langkah analisis data yang dilakukan dalam penelitian ini adalah, reduksi data, penyajian data dan kesimpulan.

1. Reduksi Data

Yang dilakukan pada tahap reduksi data adalah

a. Membuat skor setiap pilihan jawaban dengan menggunakan skala Likert sebagai berikut :

Tabel 1.

Skala Angket

\begin{tabular}{|c|c|c|}
\hline \multirow{2}{*}{$\begin{array}{c}\text { Kategori Jawaban peserta } \\
\text { didik }\end{array}$} & \multicolumn{2}{|c|}{ Skor Untuk Butir } \\
\cline { 2 - 3 } & Positif & Negatif \\
\hline STS & 1 & 4 \\
\hline TS & 2 & 3 \\
\hline S & 3 & 2 \\
\hline SS & 4 & 1 \\
\hline
\end{tabular}

Sumber : (Sugiono, 2017) 
Keterangan:

ST

$$
\begin{array}{ll}
\text { ST } & =\text { sangat tidak setuju } \\
\text { TS } & =\text { tidak setuju } \\
\text { S } & =\text { setuju } \\
\text { SS } & =\text { sangat setuju }
\end{array}
$$$$
\mathrm{S} \quad=\text { setuju }
$$

Respon siswa dapat diukur menggunakan angket melalui banyaknya hasil respon positif atau negatif tiap-tiap kategori yang diberikan. Respon dikatakan bernilai positif jika siswa merasa senang terhadap pembelajaran yang dilakukan, ketertarikan siswa terhadap pembelajaran dan minat terhadap kegiatan yang dilaksanakan. Sedangkan, respon negatif jika siswa merasa tidak senang terhadap pembelajaran, tidak tertarik terhadap pembelajaran dan tidak adanya minat terhadap kegiatan pembelajaran.

Tabel 2. Kriteria Respon Siswa

\begin{tabular}{|c|c|}
\hline Persentase & Kategori \\
\hline $25 \% \leq \%$ NRS $<43 \%$ & Tidak Positif \\
\hline $44 \% \leq \%$ NRS $<62 \%$ & Kurang Positif \\
\hline $63 \% \leq \%$ NRS $<81 \%$ & Positif \\
\hline $82 \% \leq \%$ NRS $\leq 100 \%$ & Sangat Positif \\
\hline
\end{tabular}

Sumber : (Sudjana, 2011)

b. Menghitung frekuensi responden yang memilih SS, S, TS, dan STS pada tiap item pernyataan positif dan pernyataan negatif.

c. Menghitung skor total tiap-tiap item dan menghitung persentase perolehan skor total per item.

Rumus yang digunakan adalah sebagai berikut :

$$
\% \text { NRS } \quad=\frac{\sum_{i=1}^{n} \text { NRS }}{\text { NRSmaksimum }} \times 100 \%
$$

Keterangan:

$$
\begin{array}{ll}
\% \mathrm{NRS} & =\text { Persentase Nilai Respon Siswa (NRS) } \\
\sum_{i=1}^{n} N R S & =\text { Total Nilai Respon Siswa (NRS) pada setiap item pertanyaan } \\
\text { NRS maks } & =n \times \text { skor terbaik } \\
& =n \times 4, \text { dengan } n \text { adalah banyaknya seluruh responden }
\end{array}
$$

d. Menginterpresentasikan persentase nilai respon siswa setiap item pertanyaan Saran/pendapat yang diberikan siswa pada tiap pernyataan dianalisis secara deskriftif.

\section{Penyajian data}

Setelah data direduksi, maka langkah selanjutnya adalah menyajikan data. Data hasil angket respon siswa disajikan dalam kalimat naratif dan tabel. Melalui penyajian data tersebut data akan semakin mudah untuk dipahami.

3. Penarikan kesimpulan

Langkah terakhir dalam analisis data penelitian ini adalah penarikan kesimpulan. Kesimpulan dalam penelitian kualitatif mungkin dapat menjawab rumusan masalah yang dirumuskan sejak awal. 
Respon Siswa MTs Swasta Al-UMM terhadap Pembelajaran Daring Selama Pandemi Corona, Risna Mira Bella Saragih, Khoiruddin Matondang, Nila Wati

\section{HASIL DAN DISKUSI}

\section{Hasil}

Penelitian ini bertujuan untuk mengetahui respon siswa MTs Swasta AL-UMM terhadap pembelajaran daring selama pandemi corona. Data angket respon siswa diperoleh dari sampel 45 siswa dari 15 siswa kelas VII, 14 siswa kelas VIII dan 16 siswa kelas IX. Adapun hasil respon siswa MTs Swasta AL-UMM terhadap pembelajaran daring selama pandemi corona dapat dilihat pada Tabel 3 sebagai berikut:

Tabel 3. Respon Siswa MTs Swasta AL-UMM Terhadap Pembelajaran Daring Pada Setiap Indikator

\begin{tabular}{|c|c|c|c|c|c|}
\hline No & Indikator & No Pernyataan & $\sum$ Nrs & $\% \mathrm{Nrs}$ & Kriteria \\
\hline \multirow[t]{7}{*}{1.} & \multirow{7}{*}{$\begin{array}{l}\text { Menunjukan minat terhadar } \\
\text { pembelajaran daring ditinjau da }\end{array}$} & 6 & 108 & $60 \%$ & Lemah \\
\hline & & 7 & 116 & $64,44 \%$ & Kuat \\
\hline & & 8 & 98 & $54,44 \%$ & Lemah \\
\hline & & 15 & 95 & $52,77 \%$ & Lemah \\
\hline & & 16 & 103 & $57,22 \%$ & Lemah \\
\hline & & 19 & 100 & $55,55 \%$ & Lemah \\
\hline & & 20 & 105 & $58,33 \%$ & Lemah \\
\hline \multirow[t]{7}{*}{2.} & \multirow{7}{*}{$\begin{array}{l}\text { Menunjukan minat terhadap } \\
\text { pembelajaran daring ditinjau } \\
\text { dari media pembelajaran }\end{array}$} & 4 & 97 & $53,88 \%$ & Lemah \\
\hline & & 5 & 137 & $76,11 \%$ & Kuat \\
\hline & & 9 & 94 & $52,22 \%$ & Lemah \\
\hline & & 10 & 84 & $46,66 \%$ & Lemah \\
\hline & & 12 & 93 & $51,66 \%$ & Lemah \\
\hline & & 17 & 96 & $53,33 \%$ & Lemah \\
\hline & & 18 & 94 & $52,22 \%$ & Lemah \\
\hline \multirow[t]{6}{*}{3.} & \multirow{6}{*}{$\begin{array}{l}\text { Menunjukan minat terhadap } \\
\text { pembelajaran daring ditinjau } \\
\text { dari } \\
\text { pendukung/fasilitas } \\
\text { pendukung }\end{array}$} & 1 & 77 & $42,77 \%$ & $\begin{array}{l}\text { Sangat } \\
\text { Lemah }\end{array}$ \\
\hline & & 2 & 74 & $41,11 \%$ & $\begin{array}{l}\text { Sangat } \\
\text { Lemah }\end{array}$ \\
\hline & & 3 & 103 & $57,22 \%$ & Lemah \\
\hline & & 11 & 101 & $56,11 \%$ & Lemah \\
\hline & & 13 & 108 & $60 \%$ & Lemah \\
\hline & & 14 & 95 & $52,77 \%$ & Lemah \\
\hline
\end{tabular}

Respon siswa berdasarkan minat terhadap pembelajaran daring ditinjau dari guru berkaitan dengan pembelajaran yang dilakukan oleh guru. Minat terhadap pembelajaran daring ditinjau dari media pembelajaran terdiri atas media pembelajaran yang dilaksanakan oleh guru saat mengajar. Minat terhadap pembelajaran daring ditinjau dari sarana pendukung/fasilitas pendukung yang terdiri atas sarana belajar untuk menunjang proses pembelajaran. Respon siswa dapat dilihat pada Gambar 3.

Rata-rata nilai respon siswa sebesar 57,53\% pada indikator menunjukan minat terhadap pembelajaran daring ditinjau dari guru kurang positif karena guru tidak bisa mendesain pembelajaran daring secara baik, tidak ada video pembelajaran yang diberikan guru matematika di MTs Swasta AL-UMM, guru hanya memberikan materi dari buku yang diberikan kepada siswa seminggu sekali pada hari yang telah dijadwalkan sebelumnya sekaligus latihan yang dikumpulkan semingggu yang akan datang. Guru masih kesulitan mengubah kebiasaan pembelajaran langsung menjadi pembelajaran daring. Padahal setelah pandemi ini berakhir pembelajaran daring masih layak digunakan sebagai variasi pembelajaran. Pelatihan 
dan supervisi berkala hendanya dilakukan sekolah sebagai pembekalan guru dalam menyiapkan pembelajaran.

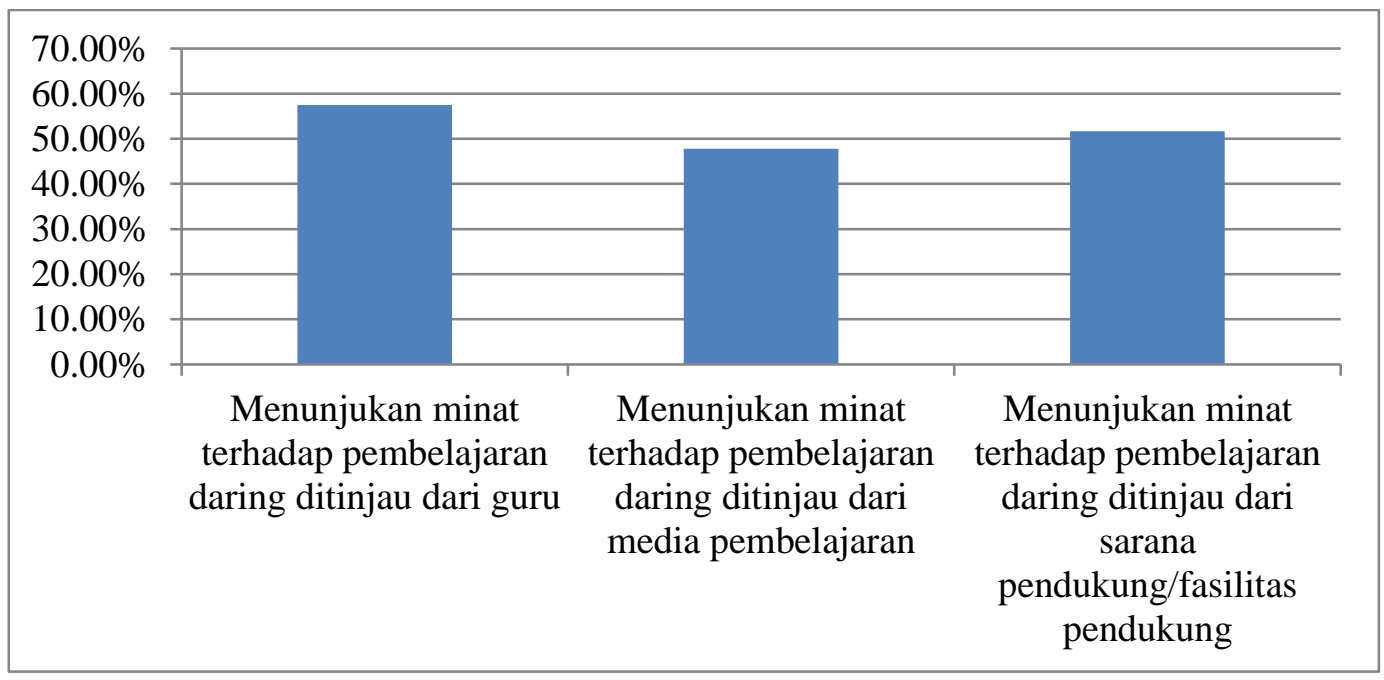

Gambar 3. Respon siswa MTS swasta AL-UMM terhadap pembelajaran Daring

Indikator siswa menunjukan minat terhadap pembelajaran daring ditinjau dari media pembelajaran kurang positif dengan rata-rata nilai respon siswa sebesar 47,77 \% dikarenakan siswa tidak dapat memahami media pembelajaran yang diberikan oleh guru kepada siswa pada masa pandemi. Guru matematika di MTs Swasta AL-UMM belum menggunakan media pembelajaran daring, guru hanya mengandalkan modul padahal banyak media pembelajaran online yang bisa digunakan guru seperti membuat materi dalam bentuk video kemudian men share di youtube atau grup whatsapp, menggunakan powerpoint, software geogebra, dll. Selama proses pembelajaran daring guru hanya memanfaatkan grup whatsapp saja. Tidak ada jalan bagi siswa jika mengalami kendala saat mengerjakan soal yang diberikan guru, dalam kondisi tersebut siswa pasrah terhadap keadaan tidak mengerjakan soal latihan akibatnya banyak nilai siswa yang kosong.

Selanjutnya indikator menunjukan minat terhadap pembelajaran daring ditinjau dari sarana pendukung/fasilitas pendukung mendapat respon dengan kurang positif dengan nilai respon siswa sebesar $51,66 \%$. Tentunya kesuksesan pembelajaran daring tidak lepas dari sarana dan fasilitas pendukung. Jaringan internet yang stabil, banyak siswa yang tempat tinggalnya yang jaringan internetnya kurang baik. Kuota paket data yang mecukupi merupakan penghambat pembelajaran online, siswa di MTs Swasta ALUMM merupakan keluarga yang perekonomiannya menengah kebawah yang mayoritas pekerjaan orangtuanya sebagai nelayan, buruh pabrik dan buruh bangunan, tidak sedikit orangtua siswa yang di rumahkan. Fasilitas pendukung yang lainnya adalah HP android atau laptop, banyak siswa yang tidak memiliki HP android, siswa harus bergantian dengan kakak, adik atau abangnya dalam pembelajaran online sehingga hal tersebut menjadi faktor kendala pembelajaran online.

Pemanfaatan media online menjadi solusi bagi siswa untul memahami pembelajaran selama pembelajaran jarak jauh (Izzah et al., 2020). Inovasi pembelajaran jarak jauh sangat menentukan keberhasilan output dari pembelajaran, guru dituntut untuk memiliki banyak cara yang bisa menarik perhatian siswa, membuat siswa menjadi aktif, memilih media pembelajan daring yang bervariasi 
Respon Siswa MTs Swasta Al-UMM terhadap Pembelajaran Daring Selama Pandemi Corona, Risna Mira Bella Saragih, Khoiruddin Matondang, Nila Wati

(Mustakim, 2020) . Mengatasi respon siswa yang kurang positif terhadap pembelajaran daring dengan merangcang pembelajaran daring matematika dengan baik, menarik dan menyenangkan bagi siswa.

Inovasi pembelajaran daring matematika bisa mengkombinasikan apliasi zoom, google classroom, google meet, quizizz, youtube. Penggunaan zoom merupakan salah satu alternatif untuk menggantikan kehadiran siswa secara virtual serta mampu menjadikan hasil pembelajaran jarak jauh menjadi lebih. Google classroom merupakan media pembelajaran yang sangat fleksibel tempat maupun waktu, efektif dalam penyampaian materi maupun pengumpulan tugas, memudahka guru mengupload power point, video maupun soal-soal (Salamah, 2020). Pemanfaatan Quizizz dapat menciptakan atmosfer pembelajaran menjadi lebih hidup, memotivasi siswa dan meningkatkan hasil belajar (Salsabila et al., 2020). Youtube dipilih dalam pengembangan media pembelajaran jarak jauh untuk menciptakan kondisi dan suasana pembelajaran yang menarik, menyenangkan dan interaktif, video pembelajaran di Youtube dapat diulang ulang kembali oleh siswa (Lasabuda, 2017) .

\section{KESIMPULAN}

Berdasarkan hasil penelitian yang telah dilakukan dapat disimpulkan bahwa respon siswa terhadap pembelajaran daring selama pandemi corona memiliki kriteria kurang positif pada aspek sikap siswa terhadap pembelajaran daring ditinjau dari guru $(57,53 \%)$, kurang positif pada aspek media pembelajaran $(47,77 \%)$ dan kurang positif pada aspek sarana pendukung/ fasilitas pendukung (51,66 \%). ditinjau dari sarana pendukung/fasilitas pendukung juga terdapat $(51,66 \%)$ dengan kriteria kurang positif. Kesimpulan dari penelitian ini adalah respon siswa MTS Swasta AL-UMM kurang positif terhadap pembelajaran daring selama pandemi Corona.

\section{UCAPAN TERIMA KASIH}

Terimakasih kami ucapkan kepada Bapak/Ibu Kepala Sekolah, seluruh guru dan siswa Yayasan Perguruan Mandiri MTs Swasta Al-UMM JL. Danau Siombak LK. I Kel. Labuhan Deli Kec. Medan Marelan yang sudah berpartisipasi dalam pelaksanaan penelitian ini.

\section{REFERENSI}

Abdul Latip. (2020). Peran Literasi Teknologi Informasi Dan Komunikasi Pada Pembelajaran Jarak Jauh

Di Masa Pandemi Covid-19. EduTeach : Jurnal Edukasi Dan Teknologi Pembelajaran, 1(2), 108116. https://doi.org/10.37859/eduteach.v1i2.1956

Auliya, R. N. (2016). Kecemasan Matematika dan Pemahaman Matematis. Formatif: Jurnal Ilmiah Pendidikan MIPA, 6(1), 12-22. https://doi.org/10.30998/formatif.v6i1.748

Baety, D, N., \& Munandar, D, R. (2021). Analisis Efektifitas Pembelajaran Daring Dalam Menghadapi Wabah Pandemi Covid-19. EDUKATIF: Jurnal Ilmu Pendidikan, 3(3), 880-889.

Fauzy, A., \& Nurfauziah, P. (2021). Kesulitan Pembelajaran Daring Matematika Pada Masa Pandemi COVID-19 di SMP Muslimin Cililin. Jurnal Cendekia : Jurnal Pendidikan Matematika, 5(1), 551- 
561. https://doi.org/10.31004/cendekia.v5i1.514

Handarini, O. I., \& Wulandari, S. S. (2020). Pembelajaran Daring Sebagai Upaya Study From Home (SFH)

Selama Pandemi Covid 19. Jurnal Pendidikan Administrasi Perkantoran (JPAP), 8(3), 496-503.

Izzah, L., Bahar, H., \& Yanti, W. (2020). Efektivitas Pembelajaran Matematika Daring Melalui Quantum

E-Learning Pada Masa Pandemi Covid-19 Di SMK Grafika. Prosiding Seminar Nasional Penelitian ..., 1, 1-10. https://jurnal.umj.ac.id/index.php/semnaslit/article/view/8823

Lasabuda, N. E. (2017). Pengembangan Media Youtube Dalam Pembelajaran Matematika (Suatu Penelitian Di SMK Kesehatan Bakti Nusantara Gorontalo). Jurnal Riset Dan Pengembangan Ilmu Pengetahuan, 2(2), 270-275.

Mustakim, M. (2020). Efektivitas Pembelajaran Daring Menggunakan Media Online Selama Pandemi Covid-19 Pada Mata Pelajaran Matematika. Al Asma: Journal of Islamic Education, 2(1), 1. https://doi.org/10.24252/asma.v2i1.13646

Padli, F., \& Rusdi. (2020a). Respon Siswa dalam Pembelajaran Online Selama Pandemi. Social Landscape Journal, 1(3), 1-7.

Padli, F., \& Rusdi, R. (2020b). Respon siswa dalam pembelajaran online selama pandemi. Social Landscape Journal, 1(3), 1-7.

Salamah, W. (2020). Deskripsi Penggunaan Aplikasi Google Classroom dalam Proses Pembelajaran. Jurnal Penelitian Dan Pengembangan Pendidikan, 4(3), 533-538. https://ejournal.undiksha.ac.id/index.php/JJL/article/view/29099

Salsabila, U. H., Habiba, I. S., Amanah, I. L., Istiqomah, N. A., \& Difany, S. (2020). Pemanfaatan Aplikasi Quizizz Sebagai Media Pembelajaran Ditengah Pandemi Pada Siswa SMA. Jurnal Ilmiah Ilmu Terapan Universitas Jambi|JIITUJ|, 4(2), 163-173. https://doi.org/10.22437/jiituj.v4i2.11605

Sudjana, N. (2011). Penilaian Hasil dan Proses Belajar Mengajar. Rosda Karya.

Sugiono. (2017). Metode Penelitian Kuantitatif, kualitatif, dan R\&D. Alfabeta.

Suhery, Putra, T., \& Jasmalinda. (2020). Studi Pengaruh Daring Learning Terhadap Hasil Belajar Matematika Kelas Iv. Jurnal Inovasi Penelitian, 1(3), 1-4.

Sukmadinata, N. S. (2017). Metode Penelitian pendidikan. Penerbit Remaja Rosdakarya.

Utami, Y. P., Alan, D., Cahyono, D., \& Indonesia, U. T. (2020). Studi at Home : Analisis Kesulitan Belajar Matematika pada Proses Pemjbelajaran Daring. Jurnal Ilmiah Matematika Realistik (JI-MR), I(1), 20-26. http://jim.teknokrat.ac.id/index.php/pendidikanmatematika/article/view/252/84

Wahyono, P., Husamah, H., \& Budi, A. S. (2020). Guru profesional di masa pandemi COVID-19: Review implementasi, tantangan, dan solusi pembelajaran daring. Jurnal Pendidikan Profesi Guru, 1(1), 51 65. http://ejournal.umm.ac.id/index.php/jppg/article/view/12462

Yustika, G. P., Subagyo, A., \& Iswati, S. (2019). Masalah Yang Dihadapi Dunia Pendidikan Dengan Tutorial Online: Sebuah Short Review. Tadbir: Jurnal Studi Manajemen Pendidikan, 3(2), 187. https://doi.org/10.29240/jsmp.v3i2.1178 